\title{
Quality assessment of thyroid ultrasound and implementation of a standard reporting template to be used in training hospitals
}

\begin{tabular}{|c|c|}
\hline \multicolumn{2}{|c|}{$\begin{array}{l}\text { Authors: } \\
\text { Sunette Claassens }{ }^{1} \\
\text { Claire Mitchell }^{2} \\
\text { Tebogo Hlabangana }\end{array}$} \\
\hline \multicolumn{2}{|c|}{$\begin{array}{l}\text { Affiliations: } \\
{ }^{1} \text { Diagnostic Radiology, } \\
\text { University of the } \\
\text { Witwatersrand, South Africa }\end{array}$} \\
\hline \multicolumn{2}{|c|}{$\begin{array}{l}\text { General Surgery, } \\
\text { University of the } \\
\text { Witwatersrand, South Africa }\end{array}$} \\
\hline \multicolumn{2}{|c|}{$\begin{array}{l}{ }^{3} \text { Diagnostic Radiology, } \\
\text { University of the } \\
\text { Witwatersrand, Chris Hani } \\
\text { Baragwanath Hospital, } \\
\text { South Africa }\end{array}$} \\
\hline \multicolumn{2}{|c|}{$\begin{array}{l}\text { Corresponding author: } \\
\text { Sunette Claassens, } \\
\text { sunbrum@gmail.com }\end{array}$} \\
\hline \multicolumn{2}{|c|}{$\begin{array}{l}\text { How to cite this article: } \\
\text { Claassens S, Mitchell C, } \\
\text { Hlabangana T. Quality } \\
\text { assessment of thyroid } \\
\text { ultrasound and } \\
\text { implementation of a stand } \\
\text { reporting template to be } \\
\text { used in training hospitals. } \\
\text { S Afr J Rad. 2017;21(1), } \\
\text { a1125. https://doi.org/ } \\
\text { 10.4102/sajr.v21i1.1125 }\end{array}$} \\
\hline \multicolumn{2}{|c|}{$\begin{array}{l}\text { Copyright: } \\
\text { (c) 2017. The Authors. } \\
\text { Licensee: AOSIS. This } \\
\text { is licensed under the } \\
\text { Creative Commons } \\
\text { Attribution License. }\end{array}$} \\
\hline \multicolumn{2}{|l|}{ Read online: } \\
\hline 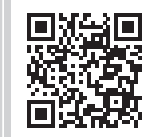 & $\begin{array}{l}\text { Scan this QR } \\
\text { code with your } \\
\text { smart phone or } \\
\text { mobile device } \\
\text { to read online. }\end{array}$ \\
\hline
\end{tabular}

Background: Ultrasound is the conventional and best imaging modality used to visualise the thyroid and thyroid-related diseases. An adequate ultrasound report can significantly influence clinicians in making management decisions in patients with such diseases.

Aim: The aim of this study was to critically assess the quality of thyroid ultrasound reports generated at Charlotte Maxeke Johannesburg Academic Hospital (CMJAH), a training hospital in Johannesburg, South Africa.

Methods: A retrospective cross-sectional study was performed. The quality of thyroid ultrasound reports was determined by using a tick sheet - a sheet having items that should be included in a thyroid ultrasound report. The contents of the tick sheet were guided by the current literature (including Thyroid Imaging Reporting and Data System [TIRADS] and Thyroid, Head and Neck Cancer Foundation [THANC]). The tick sheet was designed by the principal investigator and supervisors. The quality of reports of training radiologists, sonographers as well as qualified radiologists were documented. Comparisons of the quality of reports were made between the above groups of reporters.

Results: A retrospective analysis of thyroid ultrasound reports conducted at CMJAH revealed that the reports are of poor quality and little value to the referring clinician. The quality of the reports was poor regardless of the training level or experience of the reporter.

Conclusion: Because of the poor quality of the reports, a standard thyroid ultrasound reporting template has since been introduced at CMJAH.

Note: A selection of conference abstracts: RSSA/SASPI Paediatric Imaging Congress, 03-06 November 2016, Spier Estate, Stellenbosch, South Africa. Faculty collaborators: Professor Kassa Darge (Body Imaging University of Pennsylvania, Philadelphia, USA), Professor Edward Lee (Thoracic Imaging, Harvard University, USA), Professor Beverley Newman (Cardiac Imaging, Stanford University, California, Edward Lee (Thoracic Imaging, Harvard University, USA), Professor Beverley Newman (Cardiac Imaging, Stanford University, California, USA), Professor Kimberly Applegate (Image Gently and Body Imaging, Emory University, Atlanta, USA) and Professor Savvas Andronikou
(Thoracic Imaging, University of Bristol, UK) supported by South African Paediatric Radiologists, co-ordinated by Dr. Jaishree Naidoo, President of the African Society of Paediatric Imaging and Head of Division of Paediatric Radiology, Charlotte Maxeke Johannesburg Academic Hospital. 